October 2017

\title{
Mental Illness and the Grace of God
}

Laura K. Sjoquist

Cedarville University

Follow this and additional works at: http://digitalcommons.cedarville.edu/

bioethics_in_faith_and_practice

Part of the Behavioral Neurobiology Commons, Bioethics and Medical Ethics Commons, Cognitive Neuroscience Commons, $\underline{\text { Mental Disorders Commons, Nervous System Diseases }}$ Commons, Neurology Commons, and the Neurosciences Commons

DigitalCommons@Cedarville provides a publication platform for fully open access journals, which means that all articles are available on the Internet to all users immediately upon publication. However, the opinions and sentiments expressed by the authors of articles published in our journals do not necessarily indicate the endorsement or reflect the views of DigitalCommons@Cedarville, the Centennial Library, or Cedarville University and its employees. The authors are solely responsible for the content of their work. Please address questions to dc@cedarville.edu.

\section{Recommended Citation}

Sjoquist, Laura K. (2017) "Mental Illness and the Grace of God," Bioethics in Faith and Practice: Vol. 3 : No. 1 , Article 4. DOI: $10.15385 /$ jbfp.2017.3.1.4

Available at: http://digitalcommons.cedarville.edu/bioethics_in_faith_and_practice/vol3/iss1/4 


\section{Mental Illness and the Grace of God}

Browse the contents of this issue of Bioethics in Faith and Practice.

Please read the Senior Editor's Preview for his insight about this article.

\section{About the Author(s)}

Laura K. Sjoquist is a Cedarville University Doctor of Pharmacy Candidate currently completing her final experiential year at the Cleveland Clinic. She has a passion for neurological illnesses, particularly diseases that impact growth and development. With the support of her husband, Laura intends to pursue pharmacy residency in order to become a Developmental Clinical Pharmacist. As a prior student-athlete, Laura believes that giving back is important and she does so through mentoring programs, volunteering, organization leadership, coaching, and officiating track events.

\section{Institution/Affiliation}

Cedarville University School of Pharmacy, Doctor of Pharmacy Candidate 2018

\section{Abstract}

This paper will attempt to address God's grace towards those with mental illnesses. It also attempts to provide direction in response to historical church views towards this population. Through scripture, this paper seeks to emphasize the importance of seeing a person as more than what they physically appear capable of - seeing people through God's eyes.

\section{Keywords}

Mental illness, grace, mental disability, God's grace, grace card

\section{Creative Commons License}

\section{(c) (1) (9)}

This work is licensed under a Creative Commons Attribution-Noncommercial-No Derivative Works 4.0 License.

\section{Cover Page Footnote}

Thank you to Dr. Marty Eng, BCPPS, BCGP for inspiring the creation of this piece, and to Dr. Dennis Sullivan, MD for his editing contributions. Thank you to my father, for being a faith champion. 


\title{
Mental Illness and the Grace of God
}

\author{
Laura K. Sjoquist, PharmD candidate \\ Cedarville University
}

There is no greater disability in society, than the inability to see a person as more.

-- Robert M. Hensel

It is a Monday evening, and I am taking notes for the next day's class on mental health disorders. A section of the textbook catches my eye. In a table of Conditions that Induce Mania, one of the entries is Huntington's disease. My breath catches and my eyes stick as these words hit me with a dull, wet thump. For most people, this would have been just another item in a list to be memorized, but for me it raises a question that has often plagued my thoughts. How far does God's grace extend for someone like my father, affected by a mental illness? As I search the scriptures, I have come to believe one foundational concept: Regardless of ability, all people need the grace of Christ and should be given opportunities to accept salvation.

Throughout church history, spiritual authorities have offered a variety of explanations for mental illness. Some teach that a mental disability is a punishment for sin or for a lack of faith. Others hold that it is evidence of demonic possession, and still others believe it to be a test from God to develop virtue. Some church-goers have even suggested that the mentally ill are not "persons in the full sense," thereby questioning their autonomy and the extent of God's grace for their actions and behaviors. To truly understand what the Bible teaches about all this, we must explore the scriptural integration of the body, soul, and spirit.

In 1 Thessalonians, Paul prays for the whole sanctification the believers in Thessalonica $(5: 23)$, that their spirit, soul, and body would be preserved. Hebrews 4:12 affirms that the word of the Lord reaches and discerns the thoughts and intents of the heart. Both imply an interaction between the body, soul, and spirit: a dynamic, symbiotic relationship. This tripartite relationship is as follows: the body (brain), soul (mind, will, and emotions), and spirit (the part made alive in God). However, the presence of sin in the world has distorted the body and the mind. This becomes important when we consider the separation some Christians place between the brain and the rest of the body, separating the physical and metaphysical aspects. I believe, through my academic studies, that mental illnesses are physiological disorders. The brain is a physical organ like the rest of the body and is physically affected, similar to how the lungs are affected by the smoke of a fire.

The biblical term heart (lawbab / lebab in Hebrew, kardia in Greek) describes the heart as the center of one's being (Proverbs 4:23) where belief and faith are exercised (Luke 24:25, Romans 10:9-10). Peter describes the "hidden man of the heart" or "inner self" (1 Peter 3:4). Thus understood, the heart is the epicenter of human deliberation, the place where wisdom is applied. If understanding is the function of the mind (Job 38:36), then it has an undeniable connection to the heart, discerning right and wrong (1 Kings 3:9). Furthermore, the soul and spirit must converge with one's emotions and free will in the heart (2 Corinthians 4:16), creating the center of one's character (Matthew 15:18), or the seat of conscience and moral character: a metaphysical heart.

Bioethics in Faith and Practice vol. 3, no. 1, pp. 9-10. ISSN 2374-1597

(C) 2017, Laura Sjoquist, licensed under CC BY-NC-ND

(http://creativecommons.org/licenses/by-nc-nd/4.0/) 
When we raise questions about one's ability to make moral decisions, we essentially suggest that there are "freebie" grace cards for those with mental illnesses. But Paul reminds us that "we must all appear before the judgment seat of Christ, so that each one may receive what is due for what he has done in the body, whether good or evil" (2 Cor. 5:10). He also tells us, "For the Spirit God gave us does not make us timid, but gives us power, love and self-discipline" (2 Tim. 1:7).

To answer all those who wish to downplay the full humanity or moral capacity of the mentally ill, I have learned three important truths:

1. Stigma is an enemy of recovery, because mental illness is treatable.

2. Christians have a spiritual duty to welcome and support the mentally ill where they are, and to show them the patience and love of Christ.

3. The strength to persevere is found in God through prayer, during treatment and throughout life.

I believe God fully desires a close relationship with many like my father. He cares about their actions, their thoughts, and their behaviors, regardless of their current cognitive ability. I also believe that therapy and medications are God-honoring tools. These tools can enable those afflicted with Huntington's disease and other mental disorders to bring glory to their Heavenly Father.

And someday, I hope to have a conversation with my God about the impact those with mental illness had in expanding His kingdom. 


\section{Bibliography}

1. Henderson C. (2014). Mental Illness and the Christian Response. Retrieved July 26, 2017, from http://www.biblesprout.com/blog/mental-illness-christian-response/.

2. Lysaught M, et al. Persons with disabilities. In: On Moral Medicine: Theological Perspectives on Medical Ethics. $3^{\text {rd }}$ ed. Grand Rapids, Michigan and Cambridge UK: Wm B. Eerdmans Publishing Co; 2012:583-586.

3. Matthew Henry Commentary on the Whole Bible (complete). 1 Thessalonians 5 (2008). Retrieved July 26, 2017, from http://www.biblestudytools.com/commentaries/matthewhenry-complete/1-thessalonians/5.html

4. Matthew Henry Commentary on the Whole Bible (complete). Hebrews 4 (2008). Retrieved July 26, 2017, from http://www.biblestudytools.com/commentaries/matthew-henrycomplete/hebrews/4.html

5. Mitchell D, Snyder S. Jesus thrown everything off balance. In: Avalos H, Melcher S, Schipper J. This Abled Body: Rethinking Disabilities in Biblical Studies. Atlanta, GA: Society of Biblical Literature; 2007.

6. Viola F. (2013). 3 Christian Responses to Mental Illness; Which one is Most biblical. Retrieved July 26, 2017, from http://www.christianpost.com/news/3-christian-responses-to-mental-illnesswhich-one-is-most-biblical-93692/. 